\title{
Business Creation, Innovation, and Regional Development: Evidence from China's Thirty-Year Economic Transition
}

\author{
Shiyong Zhao ${ }^{1, *}$, Anyang Chen ${ }^{1}$, Chongxian $\mathrm{Liu}^{2}$ and Shifeng Zhao ${ }^{3}$ \\ ${ }^{1}$ School of Business, Macau University of Science and Technology \\ ${ }^{2}$ School of Economics, Beijing Wuzi University \\ ${ }^{3}$ College of Information Science, Beijing Normal University \\ ${ }^{*}$ Corresponding author
}

\begin{abstract}
Using a panel of China's 31 provinces over 19782008, we examine the effects of entrepreneurship on economic growth in the context of China's transformation from a centrally planned to a market-oriented economy. We divide entrepreneurship into two types: one is business creation and the other is innovation. Our GMM estimation results show that both types of entrepreneurship have significantly positive effects on growth rate of China's GDP per capita over the sample period. Specifically, annual growth rate will increase by 0.8-1.4 percentage points if business creation entrepreneurship (measured by non-public employment share in total urban employment) increases by 10 percentage points. And annual growth rate will increase by $0.12-0.16$ percentage points if innovation entrepreneurship (measured by number of patents granted) increases by 10 percent. Our results are robust even when we control for different sets of demographical and institutional variables. China's experience shows that an authoritarian political regime does not conflict with entrepreneurs' role.
\end{abstract}

Keywords - business creation; China; economic growth; entrepreneurship; innovation

\section{JEL Classification: L26, O15, O53}

\section{INTRODUCTION}

It is now generally recognized that entrepreneurial activity is one of the primary drivers of industrial dynamism, economic development, and growth. Entrepreneurship is central to the functioning of market economies. Joseph A. Schumpeter may be the first economist who focuses on the role of entrepreneurship in economic development. He argues that entrepreneurs drive economic growth by undertaking risky ventures that create and introduce new goods, services, and production processes that displace old businesses (Schumpeter,

1934). Lucas (1978), Baumol (1990), Murphy, Shleifer, and Vishny (1991), and Gennaioli et al. (2013) stress that the human capital of entrepreneurs plays a unique role in shaping the productivity of firms and the growth rate of entire economies.

For example, Baumol (1990) claims that the main impediment to China's industrialization during the Song Dynasty (A.D. 960-1270) was a social system that inhibited entrepreneurship, and that is why medieval China stagnated economically. The model by Zhuang (2003) suggests that economies with more entrepreneurs grow faster than those with fewer ones. Most theoretical studies suggest that entrepreneurship is of critical importance to the long-run sustainable growth of an economy, among which Porter (1990) even claims that entrepreneurship is 'at the heart of national advantage.'

It has now been quite some time that researchers have been confronting real data with ideas. Empirical evidence and the lessons of experience both seem to confirm the role of entrepreneurship in growth. Although Bosma et al. (2018) claim that 'there is very little evidence on the impact of entrepreneurship on growth,' we still find many insightful studies in the literature. Initially, much of this work was conducted on the basis of the data of the developed industrialized countries (Data availability may have had a significant role in this choice of sample). Beugelsdijk and Noorderhaven (2004) use self-employment rate as a proxy for entrepreneurship and study the growth difference of 54 European regions. They find that a high score on entrepreneurial characteristics is correlated with a high rate of regional economic growth. Glaeser (2007) uses two measures of entrepreneurship: one is self-employment rate and the other is the number of small firms. Using city data of the U.S., he finds that more entrepreneurial cities are more successful and particularly there is even a strong connection between area-level education and entrepreneurship. As more wide-ranging data sets become available, empirical regularities of the entrepreneurship-growth relationship in transition and developing economies start to draw the attention of researchers.

Inspired by the theoretical insights and empirical findings in the literature, we are going to examine the role of entrepreneurship in China's economic growth by using the provincial-level panel data of China over 1978-2008. China's transition from a bureaucratic central planning to a private market starts from 1978 and that's why our sample data set starts also from that year. As officially worded, Chinese economy was on the verge of collapse in 1978 after two decades of central planning and political movements. Then from 1978 to 2008, China had enjoyed substantial economic growth. Its GDP had been growing at an average annual rate of 9.93 percent over this period, which was historically unprecedented. It is widely recognized that the Chinese government has been playing a fairly proactive role in the economic transition and development since 1978. While in this period numerous entrepreneurs have emerged and started their businesses. By the end of 2015, the 
number of self-employed individuals and people employed in private enterprises accounted for 36 percent of the total number of employed persons in China (NBS 2016), while the number was less than 4 percent in 1990 (NBS 1991). Before 1989 there were even no officially registered private enterprises in mainland China. In a sense, China's economic reform since 1978 is a transformation from the extreme of total collectivism to greater reliance on individual initiative (entrepreneurship) and voluntary cooperation (free market). The transformation converts economic stagnation into rapid growth. The country grows more prosperous and more productive, and also grows in power and influence.

The question we are going to examine in the present paper is of special significance because we focus on China's economic transformation, which is a big phenomenon in human history. China is a trinity of a developing economy, a transition economy, and a fast-growing economy. China is also a large economy. This is a unique combination. Some previous studies have shown that entrepreneurship plays a critical role for a transition economy's success such as Russia, Poland, and Vietnam (McMillan and Woodruff 2002; Berkowitz and Dejong 2005). However, studies using China's data on the role of entrepreneurship in China's transition are far from sufficient. After all, China's transition path and growth pattern are quite different from other transition economies like Russia and East European countries (gradual reform versus shock therapy in the literature). Nobody denies the role of entrepreneurs in a free enterprise system under which private property rights are well protected and rule of law is strictly enforced. But what is the role played by entrepreneurs in a transition economy like China? In a transition economy private property rights are usually not as well protected as in the West, and rule of law is not as complete as that in the West (if not absent). By Western standards China is an authoritarian state in which government plays a leading role in institutional reform and economic development. It is not surprising that some people wonder whether entrepreneurship is stifled or at least substituted by the strong government. Some people argue that the role of entrepreneurs is limited in a country like China because governments are very strong and powerful and governments do most of the investments. They believe that economic growth in China has been mainly driven by governments' fixed investment. So governments basically supplant (rather than supplement) entrepreneurs in China's economic growth. For example, Cheung (2017) argues that China's economic miracle comes from cross-regional competition. The protagonists in the 'drama' are local officials, not entrepreneurs. Thus, it's intriguing to examine the role of entrepreneurship in China's transition under China's political regime.

\section{Model And Estimation Methods} form

The growth equation we wish to estimate has the following

$$
\log \left(\mathrm{y}_{i t} / \mathrm{y}_{i, t-1}\right)=\underset{\varepsilon_{i t}}{\beta_{1}} \log \mathrm{y}_{i, t-1}+\beta_{2} E_{i t}+\beta_{3} X_{i t}+\eta_{i}+\tau_{t}+
$$

for $i=1, \ldots, 31$ and $t=2, \ldots, 6$. Here, $\log \left(y_{i t} / y_{i, t-1}\right)$ is the $\log$ difference in per capita GDP over a five-year period, which measures the economic growth rate over this period. $\log \mathrm{y}_{\mathrm{i}, \mathrm{t}-1}$ is the logarithm of per capita GDP at the start of that period. We include it in the growth equation to test the convergence effect (i.e., whether the correlation between initial income levels and subsequent growth rates is statistically negative). $E_{i t}$ represent entrepreneurship, which include business creation and innovation entrepreneurship defined in the preceding sections.

$\mathrm{X}_{\mathrm{it}}$ are a set of control variables, which include in our growth model demographic variables like birth rate and elderly dependency ratio, human capital, FDI, government size, fixed asset investment. $\eta_{\mathrm{i}}$ stand for unobserved region-specific timeinvariant (fixed) effects, which reflect differences in the initial level of efficiency. $\tau_{t}$ are period-specific intercepts, which capture productivity changes that are common to all regions. $\eta_{i}$ and $\tau_{t}$ may also reflect region-specific and period-specific components of measurement errors. $\varepsilon_{\text {it }}$ are idiosyncratic disturbances (observation-specific errors). The subscripts i and $\mathrm{t}$ stand for region (province) $\mathrm{i}$ and period $\mathrm{t}$.

We control for FDI in the estimation equation not only because FDI itself contributes to economic growth (Zhao 2013), but also because FDI proxies for institutional quality of the host country (region). We have to include institutions into the estimation equation if we want to disentangle the role of institutions from that of entrepreneurs in the economic growth. However, institutions are very broad and complicated, which include both formal (constitutions, laws, and regulations) and informal institutions (norms, habits, social practices) (North 1990; Scott 1995; Williamson 2000). Obviously, we cannot include all these dimensions of institutions into a single growth equation, and as Bosma et al. (2018) argue, informal institutions are hard to measure consistently and precisely. Therefore, we necessarily control for only a limited set of institutional quality indicators. Our strategy is to ignore those aspects of institutions that change relatively slowly, such as constitutions and norms, etc., but focus on those aspects that change more rapidly, such as greatly improved protection of private property rights and rapidly expanded openness to the outside world. We use foreign direct investment (FDI) inflows to a region relative to regional GDP to proxy for the degree of private property protection, rule of law, and openness. The logic is straightforward. Foreign investors will not invest in a region if private property is not well protected and corruption is prevalent (grabbing-hand government). Again, this variable does not measure but only proxies for specific aspects of institutions.

The unobserved 'regional effects' $\eta_{i}$ in Eq.(1) are usually correlated with other explanatory variables including entrepreneurship, which implies that the estimates from OLS are biased and inconsistent as well (omitted variable bias). Islam (1995) suggests a panel data formulation which makes it possible to correct the bias. He divides the entire growth period into several shorter sub-periods that constitute it. Many later studies follow this approach, such as Topel (1999) and Li et al. (2009).

Following this practice, we divide the whole sample period (1978-2008) into six consecutive five-year time intervals. Thus, considering our sample period 1978-2008, we have six data (time) points for each province: 2008, 2003, 1998, 1993, 1988, and 1983. When $\mathrm{t}=1983$, for example, $\mathrm{t}-1$ is 1978 . $\log \left(\mathrm{y}_{\mathrm{it}}\right)-$ 
$\log \left(\mathrm{y}_{\mathrm{i}, \mathrm{t}-1}\right)$ is the five-year growth rate of per capita GDP from 1978 to 1983 . Then, $E_{i t}$ and $X_{i t}$ are entrepreneurship and demographic and institutional control variables averaged over 1978-1983. With this setup, as argued by Islam (1995), the error term in the regression equation are now five calendar year apart and hence may be less influenced by economic fluctuations and thus less likely to be serially correlated than they would have been in a yearly data setup. The time-invariant fixed effects in Eq.(1) can be differenced out. However, $\left(\log _{\mathrm{i}, \mathrm{t}-1}-\log _{\mathrm{i}, \mathrm{t}-2}\right)$ in the differenced equation would be correlated with the error term $\left(\varepsilon_{\mathrm{i}, \mathrm{t}}-\varepsilon_{\mathrm{i}, \mathrm{t}-1}\right)$ because $\operatorname{logy}_{\mathrm{i}, \mathrm{t}-1}$ and $\varepsilon_{\mathrm{i}, \mathrm{t}-1}$ are correlated. Therefore, essentially the difference lagged dependent variable is still endogenous.

To solve the potential endogeneity problem, we use GMM method to estimate Eq.(1). The basic idea is to estimate a system of equations in both first-differences and levels, where the instruments used in the levels equations are lagged firstdifferences of the series. System GMM method allows the introduction of more instruments, and can dramatically improve efficiency. But just because system GMM uses more instruments than differenced GMM it may not be appropriate to use system GMM with a dataset with a small number of individuals (regions in our paper). When the number of instruments exceeds the number of individuals the Sargan test may be weak. We will choose the estimation method based on the IV validity test.

To solve the endogeneity problem of the entrepreneurship variable, in the present paper we use 'the share of employees working in SOEs in total employment with a twenty-five-year lag' as an instrument for entrepreneurship (i.e., over 1953-1983). In the context of China, provinces differ in their shares of SOE sector for historical reasons (geographical considerations or resource endowments). For example, many SOEs were built in southwest China over 1960s-80s out of strategic considerations - preparation for wars with the former Soviet Union or the United States. Also many SOEs were built in northeast China because there were richly endowed with natural resources (forest, coal, and oil). These initial SOE differences drive the different levels of entrepreneurship today. Entrepreneurship had no room to develop in a region where SOEs dominated the local economy, such as northeast China. It was enough for SOE managers to routinely carry out government production plans. Under such a system, people's incentive of starting businesses or innovating was greatly constrained and even snuffed out. Conversely, in a region where SOE sector was weak, then local economy had to rely on private sector, local governments and officials would (have to) be more tolerant of private firms (against the dominating public-ownership ideology), so entrepreneurship would grow and develop, such as Zhejiang province. The different levels of entrepreneurship originated with initial government considerations in establishing SOEs persist today. Therefore, 'SOE employment share with a 25year lag', as an IV for local entrepreneurship, is relevant. The instrument is exogenous as well: SOE employment share 25 years ago should be uncorrelated with the error term in Eq.(1).

\section{THE DATA}

The data used in this paper are basically from China Compendium of Statistics 1949-2008 (NBS 2010) and China
Statistical Yearbook (relevant years). The data set includes 31 provinces of mainland China over 1978-2008 (i.e., except Hong Kong, Macau, and Taiwan). We start from 1978 because that year marks China's economic transition (reform and openingup in official wording). We choose this period because the transition since 1978 had brought astonishing changes to China. Under a centrally planned society before 1978, there was little role of entrepreneurs, or as Greenspan (2007) put it, there was no creative destruction, no impetus to make innovations. Actually whether entrepreneurs play an important role in the economy embodies a key difference between a centrally planned society and a capitalist one. China's economic reform since 1978, in a sense, is a transition from the extreme of total collectivism to greater reliance on individual initiative (entrepreneurship) and voluntary cooperation (free market).

\section{ESTIMATION RESULTS AND EXPLANATIONS}

In this section, we present the estimation results of the effects of business creation entrepreneurship and innovation entrepreneurship on economic growth in Table 1.

TABLE I. THE EFFECT OF BUSINESS CREATION AND INNOVATION ON ECONOMIC GROWTH

\begin{tabular}{|c|c|c|c|}
\hline \multirow{3}{*}{$\begin{array}{l}\text { Independent } \\
\text { variables }\end{array}$} & \multirow{2}{*}{\multicolumn{3}{|c|}{$\begin{array}{c}\text { Dependent variable: } \log \left(\mathrm{y}_{i t}\right)-\log \left(\mathrm{y}_{i, t-1}\right) \\
\text { Both business creation and innovation as } \\
\text { endogenous variables }\end{array}$}} \\
\hline & & & \\
\hline & $(1)$ & (2) & (3) \\
\hline $\log \left(y_{i, t-1}\right)$ & $\begin{array}{c}-0.561 * * * \\
(-3.30)\end{array}$ & $\begin{array}{c}-0.699 * * * \\
(-3.43)\end{array}$ & $\begin{array}{c}-0.634 * * * \\
(-3.29)\end{array}$ \\
\hline business & $\begin{array}{c}0.006 * * * \\
(2.80)\end{array}$ & $\begin{array}{c}0.004 * * \\
(2.72)\end{array}$ & $\begin{array}{c}0.003 * * \\
(2.04)\end{array}$ \\
\hline loginnovation & $\begin{array}{c}0.053 * * \\
(2.46)\end{array}$ & $\begin{array}{c}0.079 * * \\
(2.48)\end{array}$ & $\begin{array}{c}0.068 * * * \\
(2.84)\end{array}$ \\
\hline investment & $\begin{array}{l}0.000 \\
(0.05)\end{array}$ & $\begin{array}{l}-0.002 \\
(-0.68)\end{array}$ & $\begin{array}{c}-0.004^{*} \\
(-1.77)\end{array}$ \\
\hline loghuman & $\begin{array}{l}0.212^{*} \\
(1.89) \\
\end{array}$ & $\begin{array}{c}0.291 * * \\
(2.24) \\
\end{array}$ & $\begin{array}{c}0.285^{* *} \\
(2.24)\end{array}$ \\
\hline birth & & $\begin{array}{l}0.002 \\
(0.31)\end{array}$ & $\begin{array}{l}0.000 \\
(0.10)\end{array}$ \\
\hline depend & & $\begin{array}{c}0.041 * * \\
(2.60)\end{array}$ & $\begin{array}{l}0.028 \\
(1.54)\end{array}$ \\
\hline fdi & & & $\begin{array}{l}0.013^{*} \\
(1.72) \\
\end{array}$ \\
\hline government & & & $\begin{array}{l}0.005 \\
(0.98)\end{array}$ \\
\hline year dummies & Included & Included & Included \\
\hline Observations & 111 & 111 & 111 \\
\hline IV count & 17 & 23 & 29 \\
\hline $\mathrm{AR}(1)$ & 0.064 & 0.022 & 0.019 \\
\hline $\operatorname{AR}(2)$ & 0.569 & 0.853 & 0.714 \\
\hline Sargan test & 0.741 & 0.603 & 0.854 \\
\hline Hansen test & 0.360 & 0.199 & 0.336 \\
\hline
\end{tabular}

Note. All the three models are estimated with one-step difference GMM.

The results in Table 1 show that entrepreneurship, measured by business creation and innovation, plays a positive role in China's regional economic growth over thirty years of transition, and the effect is both economically and statistically significant. Our finding is consistent with the predictions of Schumpeterian growth models. While not all entrepreneurs succeed, a country with a lot of entrepreneurial activity is likely to be constantly generating new or improved products and services. Furthermore, the greater the level of development in a country, i.e., the closer 
it gets to the technology frontier, the great the role of cutting edge innovation as the motor of growth, replacing accumulation and technological catch-up (Acemoglu et al., 2006). We believe that the role of entrepreneurs in China's economic growth will be even larger in both relative and absolute terms in the future. Because the main sources of growth in China have gradually shifted from heavy fixed investment and low labor cost advantage to business creation and technological innovation, in which entrepreneurs excel. In the 2017 World Economic Forum held in Dalian of China, Chinese Premier Li Keqiang reported that since 2014 there are on average 14,000 new firms get established every day, that is, more than 5 million new enterprises come out annually. On innovation, as we mentioned above, there was no patent law in China before 1985, but by 2015 China has become the country with the largest number of patents granted in the world. The number of patents granted in China increased from 138 in 1985 to 1.72 million in 2015. The expenditure on R\&D increased from RMB 10.26 billion to RMB 1.42 trillion over the same period (Ouyang, 2017).

\section{CONCLUSION}

Our findings in the present paper are consistent with earlier observations of Banerjee and Duflo (2005) and La Porta and Shleifer (2008), who conclude that economic development occurs in regions that concentrate entrepreneurs, who run productive firms. These entrepreneurs may also contribute to the exchange of ideas, leading to significant regional externalities. Entrepreneurs (and entrepreneurship) have played a critical role in China's economic growth over the past thirty years. Based on China's provincial-level panel data over 1978-2008, we include entrepreneurship into the growth regression model and explore the impact of entrepreneurship on economic growth. We further decompose entrepreneurship into business creation entrepreneurship and innovation entrepreneurship. To alleviate the possible endogeneity problem, we use the share of employees working in SOEs in total employment with a twentyfive-year lag as an instrumental variable for entrepreneurship. The regression results show that over our sample period both business creation entrepreneurship and innovation entrepreneurship have positive effects on China's economic growth. On average, annual growth rate will increase by 0.8-1.4 percentage points if business creation entrepreneurship (measured by non-public employment share in total urban employment) increases by ten percentage points. And annual growth rate will increase by $0.12-0.16$ percentage points if innovation entrepreneurship (measured by number of patents granted) increases by 10 percent. That is to say, economy grows faster in regions with more entrepreneurship. The results are still robust even when we control for different sets of demographic and institutional variables.

\section{REFERENCES}

[1] Acemoglu, D., P. Aghion, and F. Zilibotti. 2006. "Distance to Frontier, Selection, and Economic Growth.” Journal of the European Economic Association 4(1): 37-74.

[2] Banerjee, A., and E. Duflo. 2005. "Growth Theory through the Lens of Development Economics.” In Handbooks of Economic Growth, Vol. 1a, Philippe Aghion and Steven Durlauf, eds. (Amsterdam: Elsevier).

[3] Baumol, W. 1990. "Entrepreneurship: Productive, Unproductive, and Destructive.” Journal of Political Economy 98(5): 893-921.
[4] Berkowitz, D., and D. Dejong. 2005. "Entrepreneurship and PostSocialist Growth.” Oxford Bulletin of Economics and Statistics 67(1): 2546.

[5] Bosma, N., J. Content, M. Sanders, and E. Stam. 2018. "Institutions, Entrepreneurship, and Economic Growth in Europe.” Small Business Economics, https://doi.org/10.1007/s11187-018-0012-x.

[6] Beugelsdijk, S., and N. Noorderhaven. 2004. "Entrepreneurship Attitude and Economic Growth: A Cross-Section of 54 Regions.” Annals of Regional Science 38(2): 199-218.

[7] Cheung, N. 2017. China’s Economic System. Beijing: CITIC Press.

[8] Gennaioli, N., R. La Porta, F. Lopez-de-Silanes, and A. Shleifer. 2013. "Human Capital and Regional Development." Quarterly Journal of Economics 128(1): 105-164.

[9] Glaeser, E. 2007. “Entrepreneurship and the City.” NBER Working Paper, doi:10.3386/w13551.

[10] Greenspan, A. 2007. The Age of Turbulence. The Penguin Press.

[11] Islam, N. 1995. “Growth Empirics: A Panel Data Approach.” Quarterly Journal of Economics 110(4): 1127-1170.

[12] La Porta, R. and A. Shleifer. 2008. "The Unofficial Economy and Economic Development.” Brookings Papers on Economic Activity: 275352.

[13] Lucas, R. 1978. “On the Size Distribution of Business Firms.” Bell Journal of Economics 9(2): 508-523.

[14] McMillan, J., and C. Woodruff. 2002. “The Central Role of Entrepreneurs in Transition Economies.” Journal of Economic Perspective 16(3): 153170.

[15] Murphy, K., A. Shleifer, and R. Vishny. 1991. "The Allocation of Talents: Implications for Growth.” Quarterly Journal of Economics 106(2): 503530.

[16] NBS (National Bureau of Statistics of China). 2010. China Compendium of Statistics 1949-2008. Beijing: China Statistical Press.

[17] NBS (National Bureau of Statistics of China). 2009, 1991, 2016. China Statistical Yearbook. Beijing: China Statistical Press.

[18] North, G. 1990. Institutions, Institutional Change and Economic Performance. Cambridge University Press.

[19] Ouyang, Y. 2017. "China Style Innovation: Pursuing and Surpassing.” Guangming Daily, July 30, 7.

[20] Porter, M. 1990. The Competitive Advantage of Nations. London: McMillan.

[21] Schumpeter, J. 1934. The Theory of Economic Development. Cambridge, MA: Harvard University Press.

[22] Scott. W.R. 1995. Institutions and Organizations (Vol.2). Thousand Oaks: Sage.

[23] Topel, R. 1999. “Labor Market and Economic Growth.” Handbook of Labor Economics 3(3): 2943-84.

[24] Williamson, O.E. 2000. “The New Institutional Economics: Taking Stock, Looking Ahead.” Journal of Economic Literature 38(3): 595-613.

[25] Zhao, S. 2013. "Privatization, FDI Inflow and Economic Growth: Evidence from China's Provinces, 1978-2008.” Applied Economics 45 (5): 2127-39.

[26] Zhuang, Z. 2003. "South Imitation, Entrepreneurship and Long-Run Growth.” Economic Research Journal 38(1): 62-70. 